
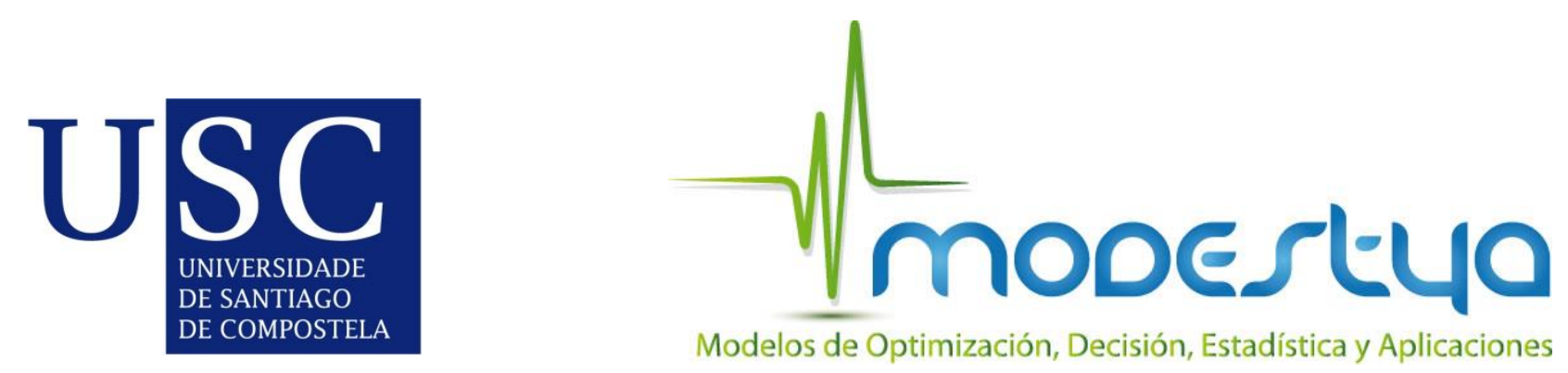

\title{
Chronicle of an early demise, surname extinction in the fifteenth and the seventeenth centuries
}

\author{
J. P. Jordà, J. Ameijeiras-Alonso and J. M. Pujadas-Mora
}

Version: pre-print

This is the Author's Original Manuscript of an article published by Taylor \& Francis in Historical Methods: A Journal of Quantitative and Interdisciplinary History on 2018, available online: http://www.tandfonline.com/10.1080/01615440.2018.1462747

\section{HOW TO CITE}

Jordá, J. P., Ameijeiras-Alonso, J., Pujades-Mora, J. M. (2018). Chronicle of an early demise, surname extinction in the fifteenth and the seventeenth centuries. Historical Methods: A Journal of Quantitative and Interdisciplinary History 51, 190-201.

\section{FUNDING}

Research has been funded by Projects MTM2016-76969-P (Spanish State Research Agency, AEI) and MTM2013-41383-P (Spanish Ministry of Economy, Industry and Competitiveness), both co-funded by the European Regional Development Fund (ERDF), IAP network from Belgian Science Policy. Work of J. Ameijeiras-Alonso has been supported by the Ph.D. Grant BES-2014-071006 from the Spanish Ministry of Economy, Industry and Competitiveness. 


\title{
Chronicle of an early demise,
}

\section{Surname extinction in the $15^{\text {th }}$ and the $17^{\text {th }}$ centuries}

\author{
Joan Pau Jordà (jpjorda@ @ed.uab.es) \\ Centre for Demographic Studies (CED), Universidade de Lisboa (UL) \\ ORCID: 0000-0003-4932-7867 \\ Jose Ameijeiras-Alonso (jose.ameijeiras@usc.es) \\ University of Santiago de Compostela (USC) \\ ORCID: 0000-0002-3122-6992 \\ Joana Maria Pujadas-Mora (jpujades@ced.uab.es) \\ Centre for Demographic Studies (CED), Autonomous University of Barcelona (UAB)
}

ORCID: 0000-0002-4975-639X. 


\begin{abstract}
It has been amply demonstrated that individuals' reproductive capability is the key explanatory phenomenon for understanding onomastic disappearance during the early modern period. This paper analyzes the evolution and consequences of surname extinction in a specific population: Catalonia in the $16^{\text {th }}$ and $17^{\text {th }}$ centuries. In this paper two aspects are examined. First, the observed disappearance of surnames is estimated through historical data collected in the Llibres d'Esposalles (Marriage Books) from 1481 to 1600 at Barcelona Cathedral. Second, the estimated natural extinction of those surnames registered in 1481 is forecast by applying a statistical branching process.
\end{abstract}

Keywords: Barcelona, Catalonia, Onomastics, Early Modern Period, Branching process, Llibres d'Esposalles (Marriage Books). 
Among 50-60\% of existing surnames disappeared from the area of Barcelona, per generation, along the sixteenth and seventeenth centuries (Sánchez-Adell 1978; Mas i Miralles 1992; Cuadrada 2003; Ferrer-Navarro 2004; Aparici 2009). This high onomastic instability is a well-known western European phenomenon, close related to those demographic events that ensure surnames transmission: births and mortality (Bourin 2010, Salinero-Testón 2010).

However, during the early modern period the area experienced a demographic revival, as it has been called by a large number of demographers and historians (Nadal and Giralt 1960; Günzberg-Moll et al. 1986; Simon 1996). The region was recovering -late and slowly- from the demographic recession caused by the crisis of the late Middle Ages (Nadal 1986) [1].

During this revival, the region grew from approximately 220,000 inhabitants in 1497 to 475,000 in 1626 (Nadal and Giralt 1960). This demographic expansion cannot be attributed solely to the natural growth of the population. Rather, it was boosted by several complementary processes, such as the Judgment of Guadalupe (1486) [2] and a significant wave of immigration from the Kingdom of France (1550-1630) [3]. Moreover, these processes were accompanied by a continuous rural flow to the cities (Lucassen and Lucassen 2009).

Generally, all European metropolises, as Barcelona, experienced in the early modern period, the so-called "urban graveyard effect", visible until the nineteenth century (Kearns 1988; Reher 2001) which implies either negative or very small 
natural population increases, as migration alone largely accounted for urban growth (Wrigley 1966; Dupâquier et al. 1995; Vries 2006; Lucassen and Lucassen 2009; Pujadas-Mora 2010).

Moreover, cities suffered important epidemic mortality crisis as it was recurring in Barcelona in 1501, 1507, 1515, 1520-1521, 1528, 1530, 1558, 1564, 15891592 and 1614 (Betran 1996; Kohn, 2007). Nevertheless, during this period Barcelona received population from the countryside, pilgrims and wanderers, Italian and Portuguese traders and thousands of French migrants which ensured the maintenance and increase of its population [4].

Given the combination of all of the factors above, it would be reasonable to think that Catalan onomastics -especially family names- experienced a series of alterations that led to significant variations in surname prevalence throughout time [5]. This study aims to analyze all these processes, focusing on surnames extinction in an urban area: Barcelona in the sixteenth and seventeenth centuries. Several authors have already analyzed the main reasons of surnames disappearances, identifying three main causes of extinction when the name was inherited according to a transmission pattern, as in the Catalan case from the thirteenth to the fifteenth centuries onwards, when surnames were transmitted along the patrilineal line (Jaggers 2009, Salinero \& Testón 2010, Jordà et al. 2016). 
Firstly, emigration, understood as a contraction of the anthroponymic corpus, could affect surname evolution. However, we must remember that during this period, Catalonia had a positive migratory balance due to the French migration wave. Secondly, the identity changes made by a very low percentage of the population could also have reduced, in minor terms, the onomastic corpus (i.e., inheritance strategies, freemen, or foundling surname). Thirdly, the lack of biological continuity of surname bearers necessarily caused the extinction of some non-frequent surnames [6]. Regarding this last point, it should be noted that surname extinction was caused not only by the death of individuals with no offspring. For example, when a couple had only daughters, the maternal surname line was extinguished in one generation as a consequence of the patrilineal transmission patterns of Catalan surnames.

From all these factors, it has been amply demonstrated that individuals' reproductive capability is the key explanatory phenomenon for understanding onomastic evolution during the early modern period (Watson and Galton 1875; Crow and Mange 1965; Yasuda et al. 1974; Kendal 1974; Lasker 1980; Tesniers 1980; Lange 1981; Brouard 1989; Manrubia and Zannette 2002).

To estimate surname extinction two aspects are examined in this study. First, the observed disappearance of surnames is estimated through historical data collected in the Llibres d'Esposalles (Marriage Licenses Books) from 1481 to 1600 at Barcelona Cathedral. Second, the estimated natural extinction of those surnames 
registered in 1481 is forecasted by applying a statistical branching process (the Galton-Watson process). This calculation is based on the probabilities of extinction of surnames obtained from the record-linkage of the marriages preserved in the Marriage License Books. The two approaches (observed and estimated extinction of surnames) are compared in order to identify possible differences. When both approaches coincide, it may be assumed that the disappearance of surnames can be explained mainly by surname bearers' lack of biological continuity. However, when they do not, other factors (e.g. migration flows, identity changes...) would necessarily have influenced the evolution of surnames.

\section{The Barcelona Historical Marriage Database (BHMD)}

The Llibres d'Esposalles of the Diocese of Barcelona offer a unique range of research opportunities thanks to their onomastic continuity. Thus, these records provide access to all the first names collected in the area of Barcelona (250 parishes in 1900) during the early modern period, facilitating the observation of the continuities and changes in the surnames registered in the Barcelona area [7]. The origin of this source dates back to the fifteenth century. In September 1409, Pope Benedict XIII (1328-1423) granted the Barcelona Cathedral a tax privilege for its construction and subsequent maintenance [8]. Therefore, every union 
celebrated in the Dioceses required, from then on, a tax payment determined by the socioeconomic status of each couple. Thus, all the information related to this tax was collected in a centralized register called the Llibres d'Esposalles (Marriage License Books or Marriage Books) (Baucells 2002) [9].

In this study, two different periods from the Barcelona Historical Marriage Database (BHMD), between the fifteenth and seventeenth centuries, have been selected (Map 1) [10]. The first period -1481-1573 (volumes 3-46)- is characterized by low population growth, while the second is one in which French immigration reaches its highest intensity -1573-1643 (volumes 47-81)- (Nadal and Giralt 1960).

\section{[MAP 1]}

The first period, again, covering the years 1481 to 1572 comprises 45,550 marriages with 4,359 different literal surnames. These surnames mainly identify each groom (99\%) as well as the priest who recorded the tax payment $(6.3 \%)$. Rarely does the bride's surname (13.5\%) appear at that time. The second period studied, 1573-1643, is part of one of the periods with the richest information in the entire BHMD, comprising 61,361 marriages and 7,661 different literal surnames. During these years marriage licenses included information on grooms' surnames $(99 \%)$ as well as the couple's parents' surnames (surname of the 
groom's father: $66.1 \%$, and surname of the bride's father: $96.9 \%$ ). In addition, when the bride had previously been widowed, there is detailed information about her deceased husband (first name, surname, occupation: $25.1 \%$ ), something that does not happen in the case of widowers (18.7\%) (Figure 1 and 2).

\section{[FIGURE 1]}

Divendres a XXXI, rebèrem deles esposalles den Gaspar Panyella, pages, de la parroquia de Sant Pere de Gelida, amb na Barthomeua doncella, filla den Anthoni Sanet de dita parroquia. Quatre sous foren generals. IIII sous.

BHMD, vol. 1499-1501, p. 27.

Friday 31, we received the betrothal of Gaspar Panella, peasant of the parish of Sant Pere de Gelida, with Barthomeua, maiden, daughter of Anthoni Sanet. Four shillings. 4 shillings.

BHMD, vol. 1499-1501, p. 27.

\section{[FIGURE 2]}

Juny 1611. Mercer. Dijous a 9 reberem de Gaspar Mercer daguer de barcelona fill de Pere mercer daguer y de Catharina defunts ab magdalena donzella filla de montserrat marti pages de barcelona y de Catharina defunts // iiii sous.

BHMD, vol. 66, p. 19a.

June 1611. Mercer. Thursday 9, we received from Gaspar Mercer, dagger from Barcelona, son of Pere Mercer dagger, and Catherina, deceased, with Magdalena, maiden daughter of Martí peasant, and Catherina, deceased. 4 shillings.

BHMD, vol. 66, p. 19a.

Moreover, from 1481 to 1643 , the Marriage Licence Books contain information about the fee paid on an eight-tiered scale [11], rising from Amore Dei for people exempt from payment of the tax to 12 for the high aristocracy (dukes, marquises, 
counts, and viscounts). Additionally, other taxes were $£ 28 \mathrm{~s}$ for noble knights and lords, the $£ 14 \mathrm{~s}$ tax for the urban oligarchy and medical doctors, the $12 \mathrm{~s}$ for merchants, and the 6s for shopkeepers, royal notaries, merchants, and master of guilds. The rest of the people, which was the majority of the society (90\%), paid 4s (peasants, artisans and laborers).

\section{Surname harmonization process}

The surname information collected in the BHMD has been subjected to a harmonization process. This is due to the fact that in Catalan, as in many languages, many family names have several variants as a result of dialectal differences and foreign influences, besides the effect of misspellings and phonetic transcriptions. Moreover, Marriage Books were recorded by different scribes with different handwritings, which led to several transcription challenges [12]. This effect is compounded by the fact that there were no formal Catalan grammar rules until the twentieth century (Bas i Vidal 1988). Consequently, all the registered variants of the same surname could produce an overestimation of the number of truly unique surnames.

There were three different levels in the harmonization process. In the first level were all the literal surnames, that is say, the same surname can have different variations. In the second, all of these variants were grouped together under their normalized form, without misspellings, in their modern Catalan equivalents (i.e. 
Farrer and Fearrer are considered as Farrer, "Smith"). In the third level, all the standardized derivations of the same surname are aggregated into a single harmonized head form (i.e. Farrer, Ferré, and Ferrer are considered as variations of Ferrer). This level is established from etymological criterion based on several dictionaries of surnames (Moll 1959; Alcover and Moll 1963; Albaigès 2006). From this process, a list of surnames is obtained in which each literal registered form from the Marriage License Books has been classified with its corresponding surname variation and its philological root (Table 1) [13]. In order to facilitate the comparability of data over time, only the husband's surname has been examined in this study, as it is the only nominative variable that is always recorded in the Marriage Books from 1481-1643 (99\% of the time). The combination of the information from the two periods selected has led to the creation of a dataset comparable over time comprising 108,997 individuals and 9,747 harmonised surnames (Table 1).

\section{[TABLE 1]}

\section{The analysis of surname extinction}

In this study, a surname is considered as having disappeared when it appears at one point in the Marriage Licenses Books but does not appear again in the following 30 years. This period is long enough to ensure that a family name could 
be transmitted from parents to children along a biological line. If an extinguished surname appears after this point it would be considered as having been reintroduced in the population [14]. In this way, four different reference periods: $1481-1510,1511-1540,1541-1570$, and 1571-1600 [15] are used in order to observe possible differences in surname evolution over time and generations. Thus, family names registered in each of these periods are also tracked in the subsequent 30 years in order to identify whether they are extinct or not in a possible second generation [16].

\section{The Galton-Watson branching process}

Surname disappearance due to the lack of biological continuity is estimated through the Galton-Watson method. This technique was designed for this purpose in the nineteenth century, and is used with some assumptions to model population reproduction systems following a fixed distribution from one generation to another [17]. Assuming that each generation is separated from the next by 30 years, the Galton-Watson branching process is defined as:

$$
\left\{Z_{n}\right\}_{n \geq 0},
$$

Where $Z_{n}$ is the number of males with the same surname in generation $n$. If we denote as $X_{n j}$ the total number of descendants of individual $j$ in generation $n$, in 
order to establish the Galton-Watson process, we need to assume that $\left\{X_{n j}: n \in\right.$ $\{0,1, \ldots\}, j \in\{0,1, \ldots\}\}$ is a sequence of independent random variables and also that the probability of having $k$ sons is always the same, that is $\mathbb{P}\left(X_{n j}=k\right)=p_{k}$, with $k \geq 0$ and having integral values. Given the above, the Galton-Watson process satisfies the following conditions:

$$
\begin{aligned}
& Z_{0}=N \in \mathbb{Z}^{+} \\
& Z_{n+1}=\left\{\begin{array}{cl}
\sum_{j=1}^{Z_{n}} X_{n j} & \text { if } Z_{n}>0, \\
0 & \text { if } Z_{n}=0 .
\end{array}\right.
\end{aligned}
$$

It must be mentioned that the use of the Galton-Watson branching process has several restrictions: First of all, it should be assumed that the probability of having $k$ sons has not changed substantially over the centuries of study, as several studies do [18]. Moreover it should be assumed that a surname present in generation $n$ would be considered extinguished if there are no observed individuals who bear it in generation $n+1$. This premise only holds if migration did not re-introduce already extinguished surnames into the observed population.

This last restriction could, initially, present a problem. In Barcelona, the sixteenth and seventeenth centuries were a period characterized by continuous migration 
flows, which could have introduced new surnames or have abnormally increased the frequency of certain surnames that otherwise would have become extinct. In this sense, it has been estimated that about $70 \%$ of the surnames listed in the Marriage Books from 1573 to 1643 could have been influenced significantly by immigration (Jordà et al. 2016). This is due to the similarities between Catalan onomastics and the surnames hold by French immigrants - mostly from the Midiwho spoke, at that time, Occitan.

Therefore, the calculations made with the Galton-Watson branching process on the information contained in the Marriage Books provide an estimate of how onomastics would have evolved with no migrations, that is to say, one depending only on the mortality rate of the population.

To compute the probability of the extinction of a surname in a given generation $l$, which we will denote as $q_{l}$, it should be noted that the probability of extinction at the initial point is 0 , with $q_{0}=0$ because it is assumed that every surname has a progenitor. From $q_{0}$ the probability of extinction of any generation can be calculated by recurrence. From a long-term perspective, there are only two possible scenarios in Galton-Watson branching processes: the number of people having the same surname can tend toward extinction or toward infinity, with the probability of extinction in the long term found in function of the value $m=$ $\sum_{k=0}^{\infty} k p_{k}<\infty$ with assured extinction when $m \leq 1$ (Harris 1989). 
Likewise, to calculate the probability of surname extinction in a given generation as well as in the long term, it is necessary to know the probability of having a particular number of sons for a father (husband as we are using marriages) in the early modern period. These probabilities were estimated through a record-linkage process based on the information contained in the BHMD which effectively resulted in five different gradually scenarios -where scenario 1 corresponds to a situation with few sons by father (Table 2).

\section{[TABLE 2]}

To compute these proportions, it has been applied software developed by the 5CofM Project, called Buscadescendències, designed specifically to reconstruct family trees. This program uses three key variables: first name of the groom, first name of the bride and surname of the groom. The Buscadescendències runs an algorithm that measures the Levenshtein distance between strings based on the method presented by Wagner and Fisher (1974). The result of all this process has been the reassembling of 5,517 potential male genealogies between 1481 and 1643, which represents $12.9 \%$ of the total number of marriages in the sixteen and seventeen centuries [19]. The reason of the reduced number of genealogies reconstructed is the fact that a record-linkage between marriages implies necessary the reconstitution of only the successful branches of a family [20]. 
It should be noted that a commonly used distribution to be applied when modeling the probability that a husband would have a certain number of children may be the Poisson distribution, where the probability of having $k$ children would be determined by the following expression:

$$
p_{k}=\left(e^{-\lambda} \lambda^{k}\right) / \mathrm{k} !, \text { with } k \in 0,1,2, \ldots
$$

With the assumption that this is the underlying distribution of the data, and with a total number of analyzed fathers equal to 1,061 , we can estimate the value of $\lambda$ (this last parameter coinciding with the mean, for the Poisson distribution) using the data provided in Table 2. These estimates are presented in Table 3.

\section{[TABLE 3]}

To test if the data follows a Poisson distribution, Pearson's chi-square test was applied [20]. For a significance level of the 5\%, there is no evidence for rejecting the null hypothesis of having this distribution in the 1 and 2 scenarios (p-values 0.6947 and 0.06247$)$. In the other three scenarios, it is rejected that the Poisson is a valid distribution (p-values $0.0030,0.0010$ and 0.0010 ). This means that we can assume that the distribution that governs the probability of having a certain number of children in the Barcelona early modern period is the Poisson 
distribution, at least in the 1 and 2 scenarios (very high and high probabilities of extinction) [21]. Therefore, assuming the Poisson distribution with the parameters estimated in Table 3, the Galton-Watson branching process could be applied to project the extinction probabilities [22], for each successive generation, starting with one father $\left(Z_{0}=1\right)$ of a surname in a theoretical population with no migration (Graph 1):

\section{[GRAPH 1]}

\section{The surnames extinction in the Barcelona area}

The estimation by the Galton-Watson branching process of surname evolution during the early modern period has shown that more than half of the cases analyzed (surnames) were extinguished before reaching the second generation (II). This extinction probability increased through successive generations, reaching a range greater than 0.75 from third generation (III). The higher the initial frequency of the surname analyzed, the lower its probability of extinction. For instance, in the hypothetical cases of analyzing surnames with initial frequencies in the first generation of 5, 10, 25, and 100 respectively, for each case the probability of extinction in the last generation studied (V) would be between 0.85 and $0.91,0.72$ and 0.830 .69 and 0.83 , and 0.004 and 0.015 . It should be noted that the statistical estimates of surnames extinction almost always coincide 
with the empirical estimations. Therefore, the data on the actual disappearance of observed surnames in the Marriage Books complement the calculated results in that they always fall within the estimated extinction ranges (Graphs 2).

\section{[GRAPH 2]}

However, certain exceptions to the extinction patterns presented can be observed, providing extra information on surname disappearances. In the historical records, surnames with an initial frequency equal or higher than 5 have very low extinction percentages, although according to the projections made, that would have been relatively likely to become extinguished (Graph 3). For instance, a surname with an initial frequency equal to 5 would have, after five generations, a probability of becoming extinct between 0.85 and 0.9 . According to these extinction patterns, of the 67 surnames with an initial frequency equal to 5, approximately 56 to 61 different surnames would became extinguished. However, in fact, only 9 of these surnames disappeared during this period (Graph 3).

\section{[GRAPH 3]}

This could be indicative that some surnames, those more frequent, would be boosted by those immigrants who carried surnames already present in Barcelona. 
A good example, well studied by authors such as Moll (1959) or Bas-i-Vidal (1988) is the French migration. These individuals carried similar surnames to the native population, which would diminish the possibility of these onomastics becoming extinct. This idea would be reinforced by the fact that the total number of surnames registered was stable throughout time: from 1,947 different surnames in $1481-1510$ to 1,977 in the period $1570-1600$.

Another possible cause of this phenomenon may have been due to the nature of our source. As a marriage record, it contains information not only on the resident population in the Barcelona area, but also on temporary migrants who were married in the region. Accordingly, it is possible that the observed disappearance rate of surnames was linked to these temporary migrants who married in the Barcelona area but then returned to their places of origin, altering partially the estimates.

\section{Surname disappearance by social group (sixteenth and seventeenth centuries)}

The estimates presented up to now on the disappearance of surnames have been complemented by the introduction of socioeconomic gradient. Thus, surnames have also been divided according to the tax levels of the Marriage Licenses Books: More than $£ 1.4 \mathrm{~s}$, Amore Dei and general fee (4s), in order to classify surname extinction by socioeconomic status. After the analysis of all groups, a mismatch has been observed between the estimated and the observed data 
collected in the Marriage Books on the poorest grooms (Amore Dei) (Graphs 4, 5 and 6).

[GRAPH 4]

[GRAPH 5]

[GRAPH 6]

Thus, an underestimate (more than $30 \%$ in some cases) in the disappearance of surnames hold by the poorest individuals has been observed when applying the Galton-Watson process (Graph 6). These results - which occur in all observed periods (1481-1510,1511-1540,1541-1570,1571-1600) - could suggest that the most disadvantaged social groups followed different onomastic patterns as compared to those of the rest of the population, with a large number of surnames disappearing from the registers from one generation to another. For instance, almost $99 \%$ of the surnames borne by Amore Dei in 1481 had disappeared from the records by $1571-1600$.

This could be due to various reasons. For example, it is very likely that in the Barcelona area the poorest strata of the population's demographic behavior was different from that of other socioeconomic groups, with high mortality rates that would have reduced the number of children per couple who reached reproductive 
age (Moya 1990; Carbonell 1998). Therefore, these reproductive deficits could have reduced the possibility of transmitting the name.

However, it should be noted that another possible reason for this phenomenon could have resulted from the continuously transient poor population of the city of Barcelona: homeless, refugees, beggars and pilgrims, as Bardet et al. (1997) and Lucassen and Lucassen (2009) among others, have been suggested. Thus, it is possible that a high number of Amore Dei married but moved after the wedding to another place outside the Barcelona area.

Surname disappearance in the Barcelona area during the early modern period (fifteenth and seventeenth centuries)

After analyzing the data collected in the Marriage Books it has been observed that around $50 \%-60 \%$ of the registered surnames throughout the period analyzed disappeared in the span of each of the generations studied.

It is noteworthy that these disappearance percentages coincide with the estimates for various locations in the Crown of Aragon during the early modern period as we were stating previously. Thus, as has already been pointed out, in all cases between $50 \%$ and $60 \%$ of the recorded surnames disappeared between each of the observation periods with the total number of surnames remaining more or less stable (Table 4). 


\section{TABLE 4}

It could said, then, that the observed extinction of surnames in the BHMD coincides with previous works, based only on observed data (Sánchez-Adell 1978; Mas i Miralles 1992; Cuadrada 2003; Ferrer-Navarro 2004; Aparici 2009). Thus, it cannot be confirmed that the characteristics of the Barcelona urban area, characterized by constant migratory flows, would have significantly affected the disappearance of surnames sufficiently to create a different extinction pattern from the rest of Catalonia. It could also indicate that all Catalonia was affected by immigration, and not just the main urban areas.

Therefore, the reproduction rates observed in the Barcelona area would not have affected surname extinction more than those observed in smaller municipalities or rural areas, such as Castelló, Onda, or Les Piles, among others. However, this, together with the estimates made using the Galton-Watson process, supports the idea that the lack of biological continuity is the key factor that explains the disappearance of the surnames from the Barcelona area between the fifteenth and seventeenth centuries. The high degree of agreement between the observed and estimated extinction of surnames would corroborate this hypothesis. Then, it may be assumed that the small number of children per couple who reached reproductive age in the early modern period, as well as the fact that only men 
transmitted their surnames in Catalonia, generated high anthroponomical variability during this period.

\section{Discussion}

This paper was seeking to contribute to model how surnames became extinct in medieval and modern Catalonia (1481 - 1643) to understand how and why some family names have survived until nowadays (which has important ties with the socio-demographic structure of populations).

This, it is not a minor issue. Onomastics have the essential function of identifying an individual. However, concurrently and indirectly, they also indicate belonging to human groups of various kinds: family, ethnic, cultural, geographical and socio-economic, providing extra information beyond that of onomastics (Colantonio et al. 2003).

Throughout this study, it has been demonstrated that the extinction of surnames projected through the Galton-Watson process coincides roughly with the observed data recorded in the Marriage Books between the fifteenth and seventeenth centuries, more precisely with the highest scenarios. This would mean that emigration or subsistence crises were not substantially significant enough to alter the natural processes of surname extinction between 1481 and 1600 due to the lack of biological continuity of their bearers, despite the patrilineal transmission system. This system could accelerate these extinction processes, as almost the 
female surname branches were excluded from naming transmission. This would be consistent with previous research (Watson and Galton 1875; Yasuda et al 1974; Kendal 1966, 1974; Jaggers 2009, Jordà et al. 2015).

Therefore the disappearance of surnames was mainly the result of a biological extinction. It could also be possible that those surnames that disappeared belonged to temporary migrants who only married in the Barcelona area, without establishing any family ties afterwards.

Almost no surnames with frequencies higher than five disappeared between the sixteenth and seventeenth centuries, although statistically - according to the Galton-Watson estimates - it should have been possible. This could means that immigration may have reintroduced many of these surnames, thereby avoiding their final extinction (i.e. immigrants carrying surnames similar to the onomastics of the area of Barcelona ensure their permanence despite ongoing biological extinction processes). In summary, the estimated and observed results are complementary.

Moreover, the surname extinction in lowest socioeconomic group, those who did not pay any fees (Amore Dei), were consistently understated when applying the Galton-Watson process in all periods analyzed (1481-1510, 1511- 1540, 15411570, 1571-1600) which could indicate some internal heterogeneity in the evolution of anthroponomy, with those surnames borne by the poorest and most disadvantaged social groups being more susceptible to extinction processes. 
Definitely, it can be affirmed that the Galton-Watson branching processes have not being the only valid methodology to determine the extinction of historical surnames but also allow to historians, linguists and demographers to assess the onomastics evolution as a whole.

Future lines of work may include the introduction of complementary sources, such as parish registers (quinque libri) or notarial documents, in order to analyze deeply the socioeconomic stratum, considering the tax payment of the used source through a multi-type branching process (see Athreya and Ney, 1971 for an introduction to this topic) or having into account the migration reproduction patterns in Barcelona during this years (see, for example Heathcote, 1965). Therefore, it could be interesting to analyze if the continuous arrival of immigrants from the Kingdom of France, mostly men at reproductive ages (Nadal and Giralt 1960), could have produced a displacement of the indigenous population in the marriage market (marriage squeeze) leaving the latter excluded from marriage affecting surnames transmission. Moreover, in futures studies it is necessary to analyze how disappearance of surnames of non-successful genealogies could be caused by other phenomena, such as immigration, mortality crisis, or changes of identity, issues that have not been possible to analyze in depth according to the available data in BHMD. 


\section{Appendix}

[TABLE 5]

[TABLE 6]

[TABLE 7]

[TABLE 8]

[TABLE 9]

\section{References}

Alcover, A.M. and F.B. Moll. 1963. Diccionari Català-Valencià-Balear, Mallorca: Editorial Moll.

Albaigès, J. 2006. El gran llibre dels cognoms catalans. Barcelona: Edicions 62. Aparici, J. 2009. Vicisitudes demográficas en Vila-Real durante el siglo XV. Saitabi, 59: 97-116.

Athreua, K.B. and P.E. Ney. 2004. Branching processes. Berlin: Springer.

Bas i Vidal, J. 1988. Els cognoms catalans i la seva història. Barcelona: Editorial de Vecchi. 
Barahona, V.L. and J. Sánchez. 1996. El trabajo en la encrucijada: los artesanos urbanos en la Europa de la Edad Moderna. Madrid: Los Libros de la Catarata.

Bertrán, J.L. La peste en la Barcelona de los Austrias. Barcelona: Editorial Milenio.

Bourin, M.; Martinez Sopena, P. 2010. Anthroponymie et Migrations dans la Chrétienté Médiévale, Madrid: Casa de Velázquez.

Brass W. 1958. The distribution of births in human populations in rural Taiwan. Population Studies 12: 51-72.

Brouard, N. 1989. L'extinction des noms de famille en France: une approche, Paris : INED.

Capdevila, A. 2013. Quan la terra promesa era el sud, Barcelona: Premi Iluro.

Carbonell, M. 1997. Sobreviure a Barcelona. Dones, pobresa i assistència al segle XVIII. Vic: Eumo.

Coale, A.J. and P. Domeny. 1983. Life Tables for Developing Countries. New York: UN Publications.

Cuadrada, C. 2003. Barcelona (ss. XIV-XV): migracions, demografia i economia. In El món urbà a la Corona d'Aragó del 1137 als Decrets de Nova Planta, 323332. Barcelona: Universitat de Barcelona.

Colantonio, S., G.W. Lasker, B. Kaplan and V. Fuster. 2003. Use of surnames models in human population biology: A review of recent developments. Human Biology, 785-807. 
Dupâquier, J; Biraben, J., Etieene, R., Pietri, C., Pietri, L., H. Bautier, and C. Klapisch-Zuber. 1995. Histoire de la population française. Des origines à la Renaissance. París: Presses universitaires de France.

Ferrer-Navarro, R. 2004. Onomàstica medieval valenciana: la comarca de la Plana Baixa. Societat d'Onomàstica: butlletí interior, 108: 157-183.

Günzberg-Moll, J., A.D. Figueras, and A.M. Almárcegui. 1986. Las crisis demográficas en Cataluña Siglos XIV al XVII: Algunas reflexiones. Contrastes: Revista de historia moderna, 2: 15-38.

Harris, T. 1989. Theory of Branching Processes, New York: Dover Publications, Heathcote, C.R. 1965. A branching process allowing immigration. Journal of the Royal Statistical Society. Series B (Methodological): 138-143.

Henry, L. 1983. Manual de demografía històrica. Barcelona: Editorial Crítica. Imaizumi, Y., N. Masatoshi, and T. Fususho. 1970. Variability and heritability of human fertility. Annals of human genètics 33, 3: 251-259.

Jaguers, P. 2009. Extinction Matematical Population Studies 16: 175-176.

Jordà, J.P., J.M. Pujadas-Mora and A. Cabré. 2014. Surnames and Migrations: The Barcelona Area (1451-1900). In Names and their Environment. Proceedings of the XXV International Congress of Onomastic Sciences, Glasgow, 25-29 August. 2014 ICOS Proceedings. Edited by C. Hough and D. Izdebska, Glasgow: University of Glasgow. 
Jordà, J.P., J.M. Pujadas-Mora and A. Cabré. 2016. Components històrics, socials i demogràfics del sistema català de nominació a l'Alta Edat Moderna: El cas dels cognoms als segles XVI i XVII Revista Recerques: història, economia, cultura 71:45-69.

Junqueras, O. 2003. Economia i pensament econòmic a la Catalunya de l'Alta Edat Moderna (1520-1630). Barcelona: Manuscrits, Universitat Autònoma de Barcelona.

Kearns, G. 1988. The Urban Penalty and the Population History of England. In Society, Health and Population during the Demographic Transition, A. Brändström and LG. Tedebrand, editors. Stockholm: Almqvist and Wiksell International: 213-236.

Kendal, D.G. 1966. Branching processes since 1873. Journal of the London Mathematical Society 41: 385-406.

Kendal, D.G. 1974. The genealogy of genealogy branching processes before (and after 1873). Bulletin of the London Mathematical Society 7, 3: 225-253.

Kohn, G.C. 2007. Encyclopedia of Plague and Pestilence: From Ancient Times to the Present. New York: Infobase Publishing.

Lange, K. 1981. Minimum extinction probability for surnames and favorable mutations. Mathematical Biosciences 54, 1: 71-78.

Lasker, G.W. 1980. Surnames in the study of human biology. American Anthropologist 82, 3: 525-538. 
Lucassen, J. and L. Lucassen. The mobility transition revisted, 1500-1900: what the case of Europe can offer to global history. Journal of Global History 4, 5: 347-377.

Madril, A. and S. Sanchís. 1990. La mortalidad en la villa de Chulilla durante los siglos XVII y XVIII. In El papel de la mortalidad en la evolución de la población valenciana. Actas del II Congreso de la Asociación de Demografía Histórica,. J.M. Bernabeu, editor. Alicante: ADEH: 45-54.

Manrubia, S.C. and D.H. Zannette. 2002. At the boundary between biological and cultural evolution: The origin of surname distributions. Journal of Theoretical Biology 264, 4: 461-477.

Mas i Miralles, A. 1992. Antroponímia i població de Santa Pola entre el 1589 i el 1877. Actes del XVIè Colloqui General de la Societat d'Onomàstica: 411-423.

Moll, F.B. 1959. Els Llinatges Catalans. Catalunya, País Valencià, Illes Balears, Mallorca: Editorial Moll.

Moyà, J.L.B. 1990. Pobreza y marginación en la Barcelona de los siglos XVI y XVII. Historia Social 8: 101-121.

Muñoz-Pradas, F. 1990. Creixement democràfic, mortalitat i nupcialitat al Penedès (segles XVII-XIX), Barcelona: Universitat Autònoma de Barcelona.

Nadal, J. 1986. La población Española: siglos XVI-XX. Barcelona: Ariel.

Nadal, J. and E. Giralt. 1960. Immigració i redreç demogràfic: els francesos a la Catalunya dels segles XVI i XVII. Vic: Eumo. 
Parker, G. 2013. Global crisis: war, climate, change and catastrophe in the seventeenth century, New Haven: Yale University Press.

Pérez-Moreda, V. and J. Nadal. 1980. La crisis de mortalidad en la España interior:(siglo XVI-XIX). Madrid: Editorial Siglo XXI.

Peytaví, J. 2010. Antroponímia, poblament i immigració a la Catalunya moderna. L'exemple dels comtats de Rosselló i Cerdanya (segles XVI-XVIII). Barcelona: Institut d'Estudis Catalans.

Plackett, R.L. 1983. Karl Pearson and the Chi-Squared Test. International Statistical Review 51, 1: 59-72.

Planas. J.M. 1987. Demografía i societat de Tàrrega durant l'Àntic Règim. Barcelona: Universitat de Barcelona.

Pujadas-Mora, J.M. 2010. L'evolució de la mortalitat infantil i juvenil a la ciutat de Palma (Mallorca, 1838-1960). Palma: Universitat de les Illes Balears.

Redal, J. 1983. Onomàstica i demografia. Els llinatges d'Alaquàs al segle XVIII. In Actes del X Col.loqui General de la Societat d'Onomàstica. València: Universitat de València: 316-319.

Reher, D.S. 2001. In search of the "urban penalty": exploring urban and rural mortality patterns in Spain during the demographic transition. In Population, Space and Place 7, 2: 105-127.

Salinero, G., and I. Teston. 2010. Un juego de engaños. Movilidad, nombres y apellidos en los siglos XV a XVIII, Madrid: Editorial Casa de Velázquez. 
Sánchez-Adell, J. 1978. Onomástica y movilidad de población la Villa de Castellón de la Plana (siglos XIV-XVIII). Saitibi 28: 33-68.

Simón, A. 1996. La població catalana a l'Edat Moderna. Deu estudis. Barcelona: Monografies Manuscrits, Universitat Autònoma de Barcelona.

Soler, J. 1985. Demografía y sociedad en Castilla la Nueva durante el Antiguo Régimen: la villa de Los Molinos, 1620-1730. Revista Española de Investigaciones Sociológicas 32: 141-192.

Tesnieres, M. 1980. L'extinction des noms de famille. Héralique et généalogie 22: 24 .

Torrents, A. 1993. Transformacions demogràfiques en un municipi industrial català: Sant Pere de Riudebitlles, 1608-1935. Barcelona: Universitat Autònoma de Barcelona.

Vilalta i Escobar, J.M. 1991. Població, familia i treball a la Lleida del segle XVI Barcelona: Universidad de Barcelona.

Vilalta i Escobar, M.J. 1997. La familia en la Lleida del siglo XVI” In Congreso Internacional Historia de la Familia: Nuevas perspectivas sobre la sociedad europea: Murcia 1994. F. Chacón and LL. Ferrer, Murcia: Universidad de Murcia: 149-160.

Villar-García, M.B. and P. Pezzi. 2003. Los extranjeros en la España moderna, Málaga: Universidad de Málaga. 
Villavicencio, F., Jordà, J.P. and J.M. Pujadas-Mora. 2015. Reconstructing lifespans through historical marriage records of Barcelona from the sixteenth and seventeenth centuries. In Population Reconstruction. G. Bloothooft, P. Christen, K. Mandemakers and M. Schraagen (editors). Berlín: Springer, Chap. 10: 199216.

Vries, De. J. 2006. European Urbanization, 1500-1800. Abigdon: Routledge. Wagner, R. and Fischer, M.J. 1974. The String-to-String Correlation Problem. In Journal of the ACM, 21: 168-173.

Watson, H.W. and F. Galton. 1874. On the probability of the extinction of families. The Journal of the Anthropological Institute of Great Britain and Ireland 4: 138-144.

Wrigley, E.A. 1967. A simple model of London's importance in changing English society and economy 1650-1750. Past and present: 44-70.

Yasuda, N., Cavalli-Sforza, LL. Skolnick, M., and A. Moroni. 1974. The evolution of surnames: an analysis of their distribution and extinction. Theoretical population biology 5, 1: 123-142. 


\section{Endnotes}

[1] The crisis of the Late Middle Ages refers to a series of famines, plagues and wars that affected population growth and prosperity in the during the fourteenth and fifteenth centuries (Simon 1996).

[2] This act was enacted by Ferdinand II of Aragon in order to resolve the conflict between the remensa peasants (who were bound to the feudal lands) and their feudal lords. Thus, this judgment allowed the peasantry to end their vassalage by paying redemptions, which facilitated peasant mobility nonexistent before (Günzberg et al. 1986; Simon 1996).

[3] The differences in salaries between France and Catalonia, the relative depopulation, and the security offered in, Catalonia as opposed to the instability during the French Wars of Religion (1560-1598) were the main reasons that drove these immigrant flows (Nadal and Giralt 1960).

[4] See for instance Moya (1990), Barahona and Sánchez (1996), Villar-García and Pezzi (2003) and Junqueras (2003) among others.

[5] This phenomenon was the consequence of the introduction of new surnames and the maintenance of those presented in the territory -boosted by the immigration. On the instability of Catalan surnames in the Barcelona area, see for instance Jordà et al. (2016).

[6] Surnames in Catalonia appeared at the beginning of the Middle Ages in association with strategies of consolidation and transfer of ownership. In the 
fourteenth century, these second names or aliases were fixed in each family, becoming from that moment onwards "family names", where children inherited the name of father along patrilineal lines (Moll 1959, Bas i Vidal 1988). It should be noted that a very small number of surnames where not transmitted following this pattern (1\%-3\% of all the marriages). Foundlings or freemen are some examples of individuals who did not carry out their lineages family names. However, these cases do not significantly affect the estimates, as it is shown in Jordà, Pujadas-Mora, Cabré (2016).

[7] No discrepancy is observed when comparing the recorded evolution of surnames in the city of Barcelona and the rest of the metropolitan area (Jordà, 2015). However, for the purposes of this study, we are going to analyze only the Barcelona urban population.

[8] Benedict XIII (Papa Luna), born Pedro Martínez de Luna, was an Aragonese nobleman who became pope during the Western Schism, when the Catholic Church split, between 1378 and 1417.

[9] These books are the historical material on which the Barcelona Historical Marriage Database is based. The compilation of the database is part of the Five Centuries of Marriages (5CofM) an advanced grant project directed by Professor Anna Cabré (CED-UAB) and funded by the European Commission through the IDEAS program of the European Research Council (ERC-2010-AdG_269796]). The research team includes scholars from the Autonomous University of 
Barcelona (UAB), the Centre for Demographic Studies (CED), and the Center for Computer Vision (CVC) (Cabré and Pujadas-Mora 2011). It should be noted that this source only allows rebuilding marriages. Therefore we analyze individuals that successfully arrived to marriageable age, which married and stay in the area of Barcelona. This successful offspring was the most probable people who contributed to the new generations of the area of Barcelona. Nevertheless, these individuals were subject to migration, the area of study acted as an attraction pole, which would facilitate the arrival new people rather than generating emigrants. Our sources of bias for the estimation of the population reproduction would be the number of infertile couples and changes on celibacy. However, during the sixteenth and seventeenth centuries the marriage levels throughout are quite stable.

[10] These books are the historical material on which the Barcelona Historical Marriage Database is based. The compilation of the database is part of the Five Centuries of Marriages (5CofM), initiative, an advanced grant project directed by Professor Anna Cabré (CED-UAB) and funded by the European Commission through the IDEAS program of the European Research Council (ERC-2010AdG_269796). The research team includes scholars from the Autonomous University of Barcelona (UAB), the Centre for Demographic Studies (CED), and the Center for Computer Vision (CVC) (Cabré \& Pujadas-Mora 2011).

[11] £1 (lliura in Catalan) is 20 shillings (sous) and 1 shilling is 12 pennies (diners). 
[12] Usually, differences appeared in surnames recorded in Catalonia due to derivations from a primitive name, such as augmentatives, diminutives, and feminizations (e.g. Pericàs, Pericot, Perica); by surname compositions of two or more names or surnames (e.g. Bon +fill > Bofill, Cap + Vila > Capdevila) or a surname and an article (e.g. La + Porta > Laporta, Sa + Font > Safont); by adding an $-s$ at the end of the surname (e.g. Prat/Prats, Company/Companys); by the persistence of archaic surname forms (e.g. Astruc-Feliç, Estela-Estrella); by variations resulting from dialectal pronunciations (e.g. Giral/Guiral, Bagué/Veguer); and by misspellings (e.g. Alemañ, Fusté). The most common changes in the spelling of family names found in the Marriages License Books are the removal of the final etymological -r (e.g. Bover/Bove, Cabrer/Cabré); changes from $a$ to $e$ when they are unstressed vowels (e.g. Bernat/Barnat, Cases/Casas); changes from unstressed $o$ to $u$ when the dialectal pronunciation is closed (e.g. Dolcet/Dulcet, Gadall/Gudall); confusion between $b$ and v; confusion between $s, c, c, z$, and $s s$; and also between $\mathrm{y}, i, j$, and $g$; and between $l$ and $l l$ (e.g. Valls/Balls, Rebull/Revull, Blai/Blay, Isern/Ysern, Pujals/Pugals); use of $c$ instead of $c h$ (e.g. Bosch/Bosc, March/Marc); and use of $h$ at the beginning of words beginning with vowels (e.g. Homs/Oms, Homdedeu/Omdedeu) (Peytaví 2010). 
[13] The BHMD has more than 142,000 variations corresponding to 35,000 different surnames. For the period 1451-1643, the database has 15,718 variations of 9,747 different surnames.

[14] The marriages of Barcelona in the fifteenth century have been taken as a reference population, analyzing their evolution over two centuries, before and after the arrival of the great French migratory waves. However, it would be risky to consider them "natives" in such a complex demographic context as Barcelona in the early modern period.

Establishing the exact timing of the appearance or extinction of a surname is not trivial. If it is not accurately matched to our data, then a rare surname with a low frequency could be considered as extinguished when really it is not so. Moreover, in contrast, an already extinguished surname could be reintroduced in our sample by immigration. While in the first case, the precipitate belief of surname demise is due to a short period of observation, in the second case, underestimation is a consequence of a long period of time. In this context, considering 30 years as a generation is a common method used by previous authors (Sánchez-Adell 1978, Redall 1983, Aparici 2009, Villavicencio 2015).

[15] For the last period, from 1601 onwards, information is only used to estimate the extinction of surnames. For this reason, the study ends with the period from 1571-1600. 
[16] Common surnames (e.g. Font, Ferrer, Serra) tend to appear year after year in the Marriage License Books. In contrast, the surnames with low frequencies were not recorded in all the volumes, appearing only in the Marriage License Books when their possible sons were recorded 25 or 30 years later. Finally, it should be noted that estimates have been made of the disappearance of surnames observed and projected according to the initial frequency of surnames in the first year of observation.

[17] See Harris (1989).

[18] Dupâquier (1995), Simon (1996), Vilalta-i-Escobar (1997), and Lucassen \& Lucassen (2010), among others.

[19] The Buscadescendències program includes certain particularities. For example, it allows the replacement of two letters by a single one ( $p h$ by $f$ or $l l$ by l) with no additional cost. Moreover, the algorithm is adapted to Catalan grammar and includes a cost system that assigns a different expense to the substitution of certain pair of letters, like for example an $a$ by an $e$, or an $o$ by a $u$. Additionally, there might be false positives due to names and surnames that are graphically very similar (only one or two letters changed), but etymologically different, like for example Piera and Riera, Casals and Canals or Guell and Amell. These cases are being included in a table of exceptions as soon as new examples come to light, in order to enhance the robustness of algorithm. The output of the program of linkage has been analyzed and processed in order to reduce the number of false 
genealogies (overlinks). Therefore, each marriage linkage has been checked, controlling that the links between surnames, social status or origin, are plausible. All these processes entail a bias, which is not significant, as it analyzes Villavicencio et al. (2015).

[20] In order to avoid potential biases such as the differences between rural and urban population or the influence of migrations on reproduction patterns, in this paper only those genealogies of men born and married in the Barcelona city are analyzed. Moreover, we have controlled the resulting genealogies dataset by tax payment, origin of the grooms and occupation, without seeing any significant difference with the general structure of the data. Also we have compared the number of sons by father between the whole Main Denary ( 0.75 sons by father) and the city of Barcelona (0.66 sons by father) obtaining similar results. Furthermore we have reconstructed the successful descendants for the 1511-1540, 1541-1570 and 1571-1600 generations, observing oscillations between 0.7 and 0.8 sons by father. The combination of all these results shows a consistence throughout time that allows us to ensure that variables as catastrophes, famines and wars did not affect substantially our estimation.

[21] See, for instance, Plackett (1983).

[22] Assuming the Poisson distribution, the probability of final extinction is equal to one if the value of $\lambda$ is less or equal to one. Thus, by seeing the estimated value of $\lambda$ is in all the cases below 0.6 it is an indicative that, for all the studied 
scenarios, the probability of extinction in the long term should be equal to one. Starting with one progenitor, at short term, the extinction probability of the generation $\mathrm{l}$ can be calculated by recurrence using the following expression $\mathrm{q}_{\mathrm{l}}=$ $\exp \left(\lambda\left(\mathrm{q}_{\mathrm{l}-1}-1\right)\right)$, with $\mathrm{q}_{0}=0$ and $\mathrm{l}=1,2, \ldots$ 
Map 1. Spanish Monarchy, Catalonia and the Diocese of Barcelona



Source: 5CofM Project

Figure 1. Marriage License from the period 1481-1573 (volumes 3-46)



Source: 5CofM Project

Figure 2. Marriage License from the second period 1573-1643 (volumes 47-81),

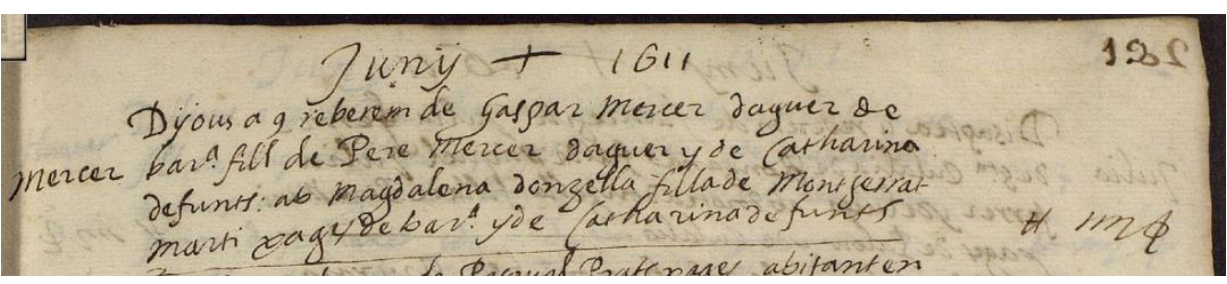

Source: 5CofM Project

Table 1. Levels of the Surname Harmonization Process: the Ferrer (Smith) case

\begin{tabular}{|c|c|c|}
\hline LITERAL & NORMALIZED & HARMONIZED \\
\hline farrer & Farrer & ferrer \\
\hline Deferrer & Ferrer & Ferrer \\
\hline fferrer & Ferrer & Ferrer \\
\hline ffarrer & Farrer & Ferrer \\
\hline ferrer & Ferrer & Ferrer \\
\hline farre & Farre & Ferrer \\
\hline ferrera & Ferrer & Ferrer \\
\hline
\end{tabular}




\begin{tabular}{|c|c|c|}
\hline farres & farres & ferrer \\
\hline
\end{tabular}

Table 2. Proportion of the number of sons reaching reproductive ages (effective reproduction).

\begin{tabular}{|c|c|c|c|c|c|c|}
\hline \multirow{2}{*}{$\mathrm{n}^{\text {o }}$} & \multirow{2}{*}{ Offspring } & \multicolumn{5}{|c|}{ scenarios } \\
\cline { 3 - 7 } & & 1 & 2 & 3 & 4 & 5 \\
\hline 0 & Childless & 0,40000 & 0,30000 & 0,20000 & 0,15000 & 0,10000 \\
\hline 1 & Son & 0,2770 & 0,32394 & 0,37022 & 0,39336 & 0,41649 \\
\hline 2 & Sons & 0,04637 & 0,05410 & 0,06183 & 0,06569 & 0,06956 \\
\hline 3 & “ “ & 0,00735 & 0,00858 & 0,00980 & 0,01041 & 0,01103 \\
\hline 4 & “ “ & 0,00057 & 0,00066 & 0,00075 & 0,00080 & 0,00085 \\
\hline
\end{tabular}

Table 3. Estimated values of $\lambda$ assuming the Poisson distribution

\begin{tabular}{|c|c|c|c|c|c|}
\cline { 2 - 6 } \multicolumn{1}{c|}{} & \multicolumn{5}{c|}{ scenarios } \\
\cline { 2 - 6 } \multicolumn{1}{c|}{} & 1 & 2 & 3 & 4 & 5 \\
\hline$\hat{\lambda}$ & 0,3947 & 0,4605 & 0,5263 & 0,5592 & 0,5921 \\
\hline
\end{tabular}

Graph 1. Example of surname extinction probability throughout four generations, starting with one progenitor $\left(Z_{0}=\right.$ 1).

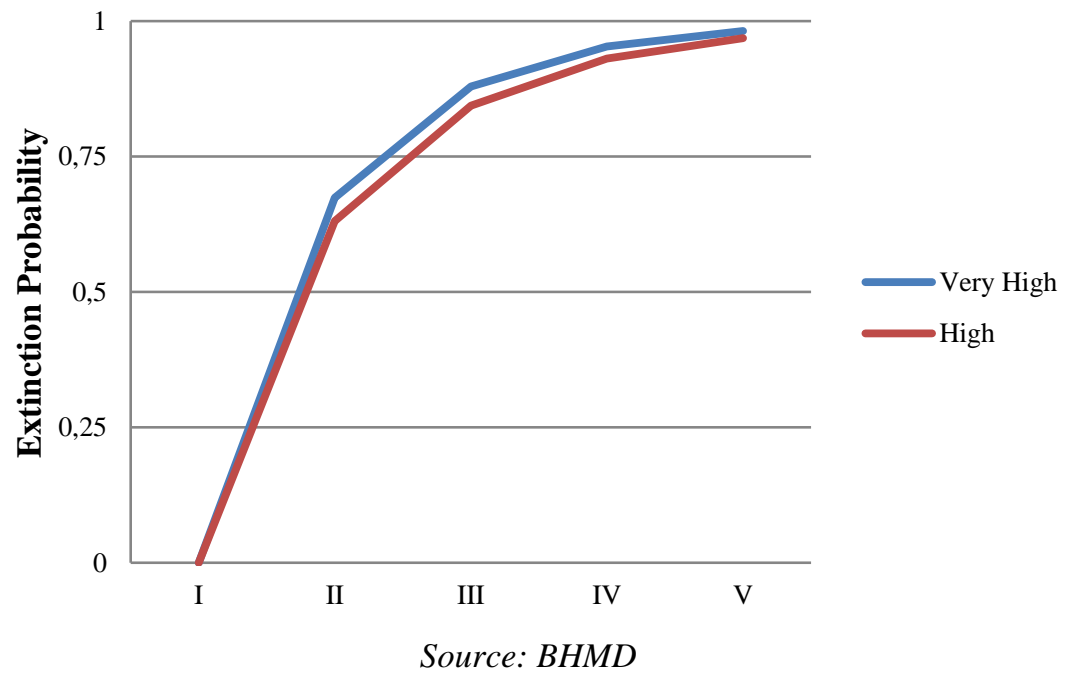


Graph 2. Surname evolution: Estimated and real number of extinguished surnames (one progenitor) through different generations (initial $\mathrm{Z}_{0}=1$ ).



Graph 3. Surname evolution: Estimated and real number of extinguished surnames (five progenitors) through different generations (initial $\mathrm{Z}_{0}=5$ ).

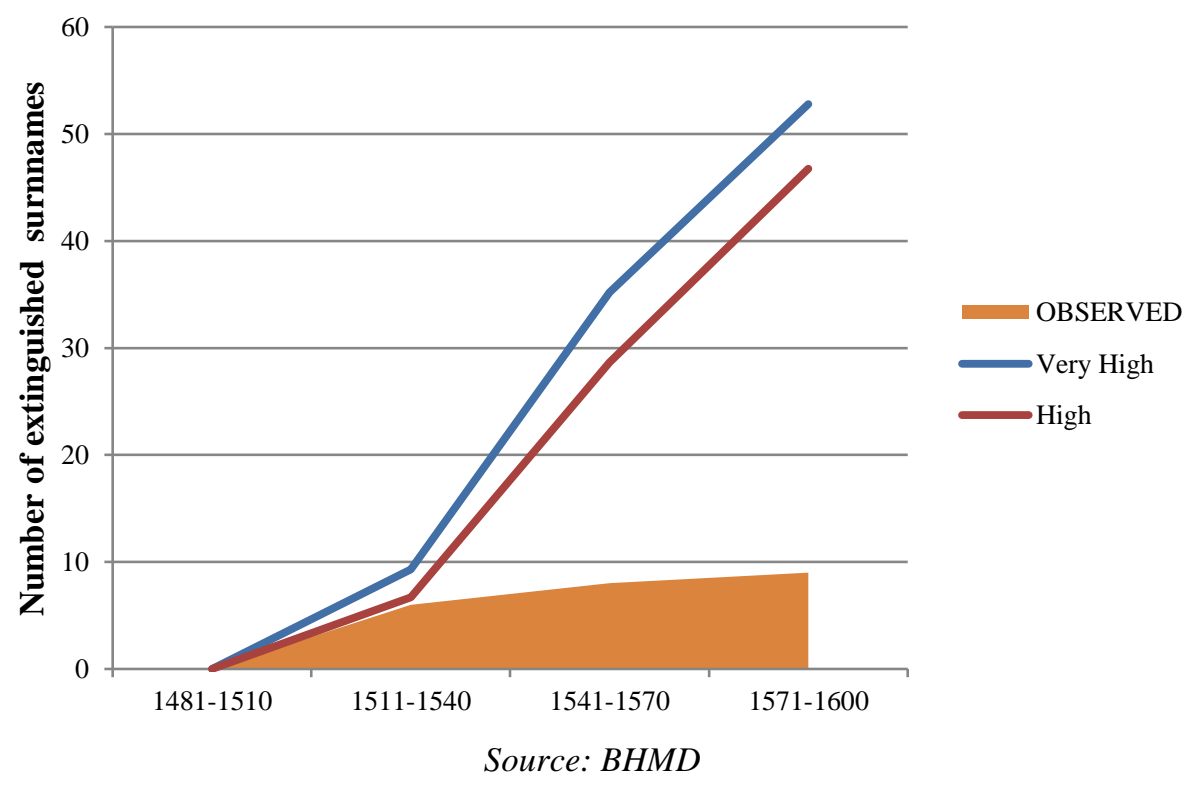


Graph 4. Surname evolution: Estimated and real number of extinguished surnames (one progenitor) in $4 \mathrm{~s}$ tax group through different generations (initial $\mathrm{Z}_{0}=1$ ).

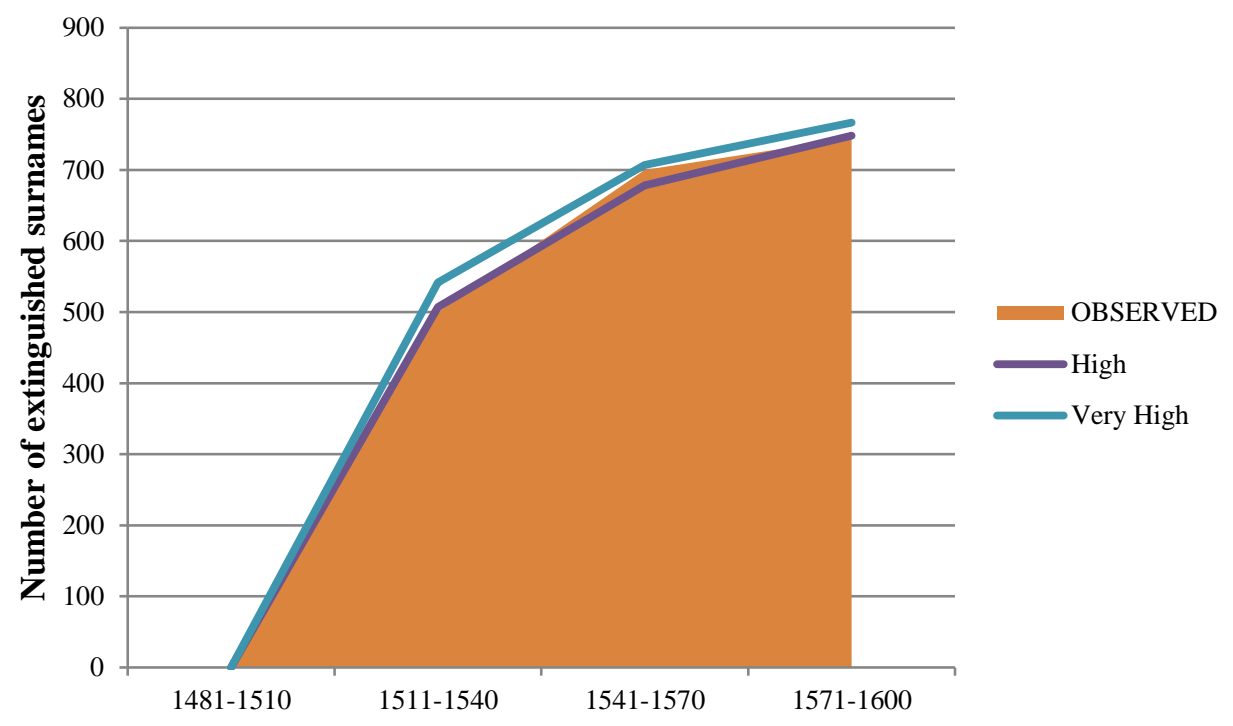

Source: $B H M D$

Graph 5. Surname evolution: Estimated and real number of extinguished surnames (one progenitor) in $£ 14 \mathrm{~s}$ tax and above group through different generations (initial $\mathrm{Z}_{0}=1$ ).

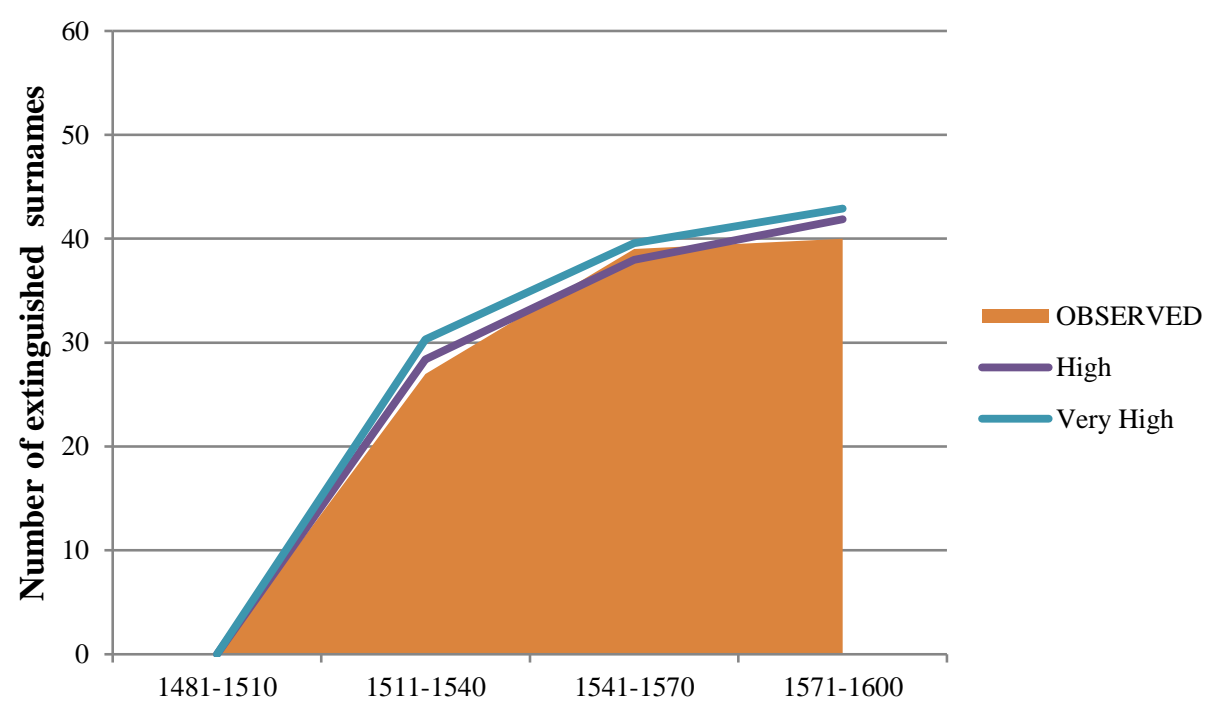

Source: BHMD 
Graph 6. Surname evolution: Estimated and real number of extinguished surnames (one progenitor) in Amore Dei tax group through different generations (initial $\mathrm{Z}_{0}=1$ ).




Table 4. Appearance, permanence and extinction of surnames from the Catalan onomastic domain

\begin{tabular}{|c|c|c|c|c|}
\cline { 3 - 5 } \multicolumn{2}{c}{} & \multicolumn{3}{|c|}{ SURNAMES (\%) } \\
\hline \multirow{2}{*}{ Municipality } & Years & Appearance & Permanence & Extinction \\
\hline Castelló & 1468 & 45.5 & 42.7 & $\mathbf{5 7 . 3}$ \\
& 1510 & 43.5 & 53.3 & $\mathbf{4 6 . 7}$ \\
& 1588 & 71.6 & 52.2 & $\mathbf{4 8 . 8}$ \\
& 1646 & 53.3 & 58.3 & $\mathbf{4 1 . 7}$ \\
& 1769 & 67.3 & 34.7 & $\mathbf{4 4 . 1}$ \\
\hline Onda & 1385 & 25.3 & 55.9 & $\mathbf{6 3 . 4}$ \\
& 1415 & 31.3 & 36.6 & $\mathbf{3 5 . 1}$ \\
\hline Vila Real & 1481 & 42.7 & 65.9 & $\mathbf{3 7 . 1}$ \\
& 1510 & 47.2 & & $\mathbf{4 9 . 7}$ \\
\hline Santa Pola & 1445 & 29.2 & 62.9 & \\
& 1481 & 41.1 & 50.3 & \\
\hline Les Piles & 1510 & 55.8 & & \\
& 1589 & & 45.7 & \\
\hline Barcelona City & 1668 & & 56.2 & $\mathbf{4 9 . 9}$ \\
\hline & 1714 & & 57.3 & $\mathbf{6 2 . 0}$ \\
\hline
\end{tabular}

From: Sánchez-Adell 1978, Mas i Miralles 1992, Cuadrada 2003, Ferrer-Navarro 2004, and Aparici 2009. 
Table 5. Surname evolution: Estimated and real number of extinguished surnames (one progenitor) through different generations (initial $\mathrm{Z}_{0}=1$ ) (proportions related to Graph 2).

\begin{tabular}{|c|c|c|c|}
\cline { 2 - 4 } \multicolumn{1}{c|}{} & $\begin{array}{c}\text { Very } \\
\text { High }\end{array}$ & High & $\begin{array}{c}\text { Observed } \\
\text { data }\end{array}$ \\
\hline $1481-1510$ & $00.0 \%$ & $00.0 \%$ & $00.0 \%$ \\
\hline $1511-1540$ & $67.4 \%$ & $63.1 \%$ & $62.1 \%$ \\
\hline $1541-1570$ & $87.9 \%$ & $84.4 \%$ & $81.9 \%$ \\
\hline $1571-1600$ & $95.3 \%$ & $93.1 \%$ & $94.3 \%$ \\
\hline
\end{tabular}

Source: BHMD

Table 6. Surname evolution: Estimated and real number of extinguished surnames (five progenitors) through different generations (initial $\mathrm{Z}_{0}=5$ ) (proportions related to Graph 3).

\begin{tabular}{|c|c|c|c|}
\cline { 2 - 4 } \multicolumn{1}{c|}{} & $\begin{array}{c}\text { Very } \\
\text { High }\end{array}$ & High & $\begin{array}{c}\text { Observed } \\
\text { data }\end{array}$ \\
\hline $1481-1510$ & $00.0 \%$ & $00.0 \%$ & $00.0 \%$ \\
\hline $1511-1540$ & $13.9 \%$ & $10.0 \%$ & $09.0 \%$ \\
\hline $1541-1570$ & $52.5 \%$ & $42.8 \%$ & $11.9 \%$ \\
\hline $1571-1600$ & $78.8 \%$ & $69.8 \%$ & $13.4 \%$ \\
\hline
\end{tabular}

Source: $B H M D$

Table 7. Surname evolution: Estimated and real number of extinguished surnames (one progenitor) in $4 \mathrm{~s}$ tax group through different generations (initial $\mathrm{Z}_{0}=1$ ) (proportions related to Graph 4).

\begin{tabular}{|c|c|c|c|}
\cline { 2 - 4 } \multicolumn{1}{c|}{} & $\begin{array}{c}\text { Very } \\
\text { High }\end{array}$ & High & $\begin{array}{c}\text { Observed } \\
\text { data }\end{array}$ \\
\hline $1481-1510$ & $00.0 \%$ & $00.0 \%$ & $00.0 \%$ \\
\hline $1511-1540$ & $67.4 \%$ & $63.1 \%$ & $62.2 \%$ \\
\hline $1541-1570$ & $87.9 \%$ & $84.4 \%$ & $87.1 \%$ \\
\hline $1571-1600$ & $95.3 \%$ & $93.1 \%$ & $92.7 \%$ \\
\hline
\end{tabular}

Source: $B H M D$ 
Table 8. Surname evolution: Estimated and real number of extinguished surnames (one progenitor) in $£ 14 \mathrm{~s}$ tax group through different generations (initial $\mathrm{Z}_{0}=1$ ) (proportions related to Graph 5).

\begin{tabular}{|c|c|c|c|}
\cline { 2 - 4 } \multicolumn{1}{c|}{} & $\begin{array}{c}\text { Very } \\
\text { High }\end{array}$ & High & $\begin{array}{c}\text { Observed } \\
\text { data }\end{array}$ \\
\hline $1481-1510$ & $00.0 \%$ & $00.0 \%$ & $00.0 \%$ \\
\hline $1511-1540$ & $67.4 \%$ & $63.1 \%$ & $59.1 \%$ \\
\hline $1541-1570$ & $87.9 \%$ & $84.4 \%$ & $80.6 \%$ \\
\hline $1571-1600$ & $95.3 \%$ & $93.1 \%$ & $90.3 \%$ \\
\hline
\end{tabular}

Source: $B H M D$

Table 9 Surname evolution: Estimated and real number of extinguished surnames (one progenitor) in Amore Dei tax group through different generations (initial $\mathrm{Z}_{0}=1$ ) (proportions related to Graph 6).

\begin{tabular}{|c|c|c|c|}
\cline { 2 - 4 } \multicolumn{1}{c|}{} & $\begin{array}{c}\text { Very } \\
\text { High }\end{array}$ & High & $\begin{array}{c}\text { Observed } \\
\text { data }\end{array}$ \\
\hline $1481-1510$ & $00.0 \%$ & $00.0 \%$ & $00.0 \%$ \\
\hline $1511-1540$ & $67.4 \%$ & $63.1 \%$ & $83.3 \%$ \\
\hline $1541-1570$ & $87.9 \%$ & $84.4 \%$ & $91.7 \%$ \\
\hline $1571-1600$ & $95.3 \%$ & $93.1 \%$ & $99.1 \%$ \\
\hline
\end{tabular}

Source: $B H M D$ 